\title{
ЭФФЕКТИВНОСТЬ ОРИГИНАЛЬНЫХ СУКЦИНАТСОДЕРЖАЩИХ СРЕДСТВ ДЛЯ КОРРЕКЦИИ ПРО-/АНТИОКСИДАНТНОГО ГОМЕОСТАЗА ПРИ ЭНДОКРИНОПАТИЯХ
}

\author{
Палагина И.А., Кудря М.Я., Мельниковская Н.В., Кустова С.П.
}

ГУ «Институт проблем эндокринной патологии им. В.Я. Данилевского НАМН Украины», г. Харьков, Украина

Дисбаланс свободнорадикального окисления (СРО) и антиоксидантной системы (АОС) является одним из патогенетических механизмов большинства эндокринопатий. Оригинальное антидиабетическое средство на основе $\beta$-фенилэтиламида 2-оксисукцинаниловой кислоты (ФЭАОСАК) с антиоксидантной активностью является перспективным для коррекции метаболического синдрома (МС). На основе производного камфорной кислоты и сукцината разработана фармацевтическая композиция (ФК) для коррекции коморбидной патологии: нарушений сперматогенеза и функционального состояния печени.

ЦЕЛЬ: изучить влияние ФЭАОСАК и ФК - производных дикарбоновых кислот на процессы свободнорадикального окисления при эндокринопатиях.

МАТЕРИАЛЫ И МЕТОДЫ: ФЭАОСАК вводилИ перорально в эффективной дозе 50 мг/кг м.т./5 недель крысам-самкам с постменопаузальным МС, вызванным овариоэктомией и введением 30\%-ной сахарозы/5 недель (модель 1). ФК вводили в терапевтической дозе 32 мг/кг м.т./перорально/1мес. крысам-самцам с нарушениями сперматогенеза на фоне гепатита, индуцированного тетрахлорметаном (2,5 мл/кг/подкожно/1 мес. - модель 2) и парацетамолом (500 мг/кг м.т/ перорально/1 мес. - модель 3). Определяли содержание диеновых конъюгатов (ДК), гидроперекисей липидов (ГПЛ), ТБК-активных соединений (ТБКАС), продуктов окислительной модификации белков (ОМБ): карбонилированных белков $\left(\mathrm{KБ}_{370^{\prime}}, \mathrm{KБ}_{430}\right)$, метаболитов $\mathrm{NO}: \mathrm{NO}_{2}^{-}, \mathrm{NO}_{3}{ }^{-}$, восстановленного глутатиона (ВГл), активность супероксиддисмутазы (СОД), каталазы, глутатион-зависимых ферментов в сыворотке, цельной крови и гомогенате печени.

РЕЗУЛЬТАТЫ: на модели 1 показано, что ФЭАОСАК снижает содержание ДК и ГПЛ в сыворотке крови и печени, что противоположно сдвигам показателей у крыс с МС. При этом восстанавливается активность процессов ОМБ в виде увеличения содержания в сыворотке крови КБ ${ }_{370}$ и КБ ${ }_{430}$ до уровня интактного контроля. Зафиксировано снижение в печени и плазме крови содержания $\mathrm{NO}_{2}^{-}$и $\mathrm{NO}_{3}$, генерируемых при MC, а также повышение уровня ВГл в сыворотке крови, активности СОД и глутатион-S-трансферазы (ГST) в печени.

На модели 2 и 3 выявлена сниженная активность АОС, изменения интенсивности СРО в виде повышения активности ПОЛ и образования стабильных метаболитов NO в печени и организме в целом. ФК на модели 2 усиливает антиоксидантную защиту организма за счет стимуляции синтеза глутатиона и увеличения количества SH-групп белков в ткани печени, снижает интенсивность реакций ПОЛ и обмена NO, в результате чего уменьшается содержание ГПЛ, ТБКАС, $\mathrm{NO}_{2}^{-}$и $\mathrm{NO}_{3}^{-}$в ткани печени, ДК - в сыворотке крови. На модели 3 ФК стимулирует АОС с повышением содержания ГлВ в крови и активности ГSТ в ткани печени, что сопровождается нормализацией реакций ПОЛ в печени и крови. Коррекция прооксидантноантиоксидантного гомеостаза воздействием ФК способствуют восстановлению метаболических процессов в печени, в том числе связанных со сперматогенезом.

ВЫВОды: $\beta$-фенилэтиламид 2-оксисукцинаниловой кислоты и фармкомпозиция на основе производного камфорной кислоты и сукцината, обладая выраженной антиоксидантной активностью, нормализуют реакции липопероксидации, карбонилирования белков и нитрозилирования, что позитивно влияет на состояние метаболических процессов в организме при эндокринопатиях.

КЛЮЧЕВЫЕ СЛОВА: сукцинатсодержащие средства; про- и антиоксидантный гомеостаз; метаболический синдром, нарушения сперматогенеза. 